\title{
メニエール病の自律神経機能についての考察
}

荻 野化

\section{Autonomic Nervous Function of Patients with Meniere's Disease}

\author{
Hitoshi Ogino \\ (Otemae Hospital)
}

To clarify the autonomic nervous function in patients with Meniere's disease, the following tests were carried out;

1. General autonomic nervous function tests,

1) Tone of the sympathetic nervous system,

2) Sensitivity of adrenergic receptors,

3) Sympathetic and parasympathetic nervous activity,

4) Reflex functions of autonomic nervous system,

2. Local autonomic nervous function tests,

1) Ice water immersion test,

2) Ashner's test,

3) Forehead cooling test,

Many patients exhibited decreased parasympathetic nervous activity in any stage and laterality differences in cervical sympathetic nervous function in attack stage. So I considered that the decreased activity of parasympathetic nervous activity was predisposition and laterality differnces in cervical sympathetic nervous function was induced factor in Meniere's disease.

Key words: Meniere's disease, general autonomic nervous function, local autonomic nervous function

\section{はじめに}

生体には, 時々刻々変化する外部環境に対し て, 内部環境を一定に保ち平衡状態に維持する 能力, すなわち homeostasis の機能が存在する ことが知られている.自律神経系が，この homeostasis に重要な役割をはたすことは衆知 の事実であるが，もし自律神経系が全身的，あ るいは局所的に障害されれば，さまざまな疾患 が生じることが考えられる。奉際に，主として 内科領域において表 1 に示した各種疾患が，自
律神経障害に起因するとされている1).

同様に耳鼻咽喉科領域においても, 多数の疾 患で自律神経との関連が報告されている.耳鼻 咽喉科疾患と自律神経との関連性は, 耳鼻咽喉 科領域の多くの臓器が, 自律神経の直接の支配 を受けており，さらに血流を介して間接的に影 響を受けているといら解剖学的事実より, 十分 に首肯できるが，他にもいくつかの理由が考光 られる.耳鼻咽喉科領域には多数の感覚器があ り，その訴えが主観的で機能性障害であること 
が多いため，疾患の原因を直接眼にみえないも の，たとえば自律神経のせいにする可能性が考 えられる。あるい，いわゆる自律神経失調症 と呼ばれる症例で，耳鼻咽喉科領域の訴光（め まい，のどの不快感など）が高率に認められる ため，逆にこれらの訴えは自律神経異常に起因 する可能性が高いと考えられることも，理由の
ひとつと言える.

いずれにしても，耳鼻咽喉科疾患と自律神経 機能とは深い関連を有すると言えるが，結論は 必ずしもでていないのが現状である，その理由 のひとつとして，表1に示した疾患の多くは自 律神経系に器質的な障害が生じており, 自律神 経機能検査の結果が常に一定（低下）であるの

表 1 自律神経疾患の分類

I）全身性機能障害

1. 原 発 性

a：進行性自律神経障害 progressive autonomic failure (PAF)

b : 多臓器萎縮を伴う進行性自律神経障害 PAF with multiple system atrophy (MSA); Shy-Drager 症候 群, リポジストロフィー, 進行性顔面半側萎縮症

2. 二 次 性

$\mathrm{a}$ ：全身性疾患；糖尿病，アミロイドーシス

b : 自己免疫疾患; 急性 (亜急性) dysautonomia, Guillain-Barre 症候群, 筋無力症, 関節リウマチ

c：癌性自律神経障害

$\mathrm{d} ：$ 代謝疾患; ポルフィリン症, Tangier 病, 遺伝性 $\alpha$ リポ蛋白欠乏症, Fabry 病

$\mathrm{e}:$ 遺伝子知覚神経障害

$\mathrm{f}$ : 神経系の感染症; 梅毒, Chagas 病

$\mathrm{g}:$ 中枢性脳疾患

$\mathrm{h}:$ 春髄疾患

i ：家族性 dysautonomia; Riley-Day 症候群

$\mathrm{j}:$ 家族性ブラディキニン機能立進症

3. 薬 剤 性

a : 選択的神経毒薬剤；アルコール中毒, Wernicke 脳症

b : 精神安定剂 ; フェノチアジン, バルビタール剤

c : 抗らつ威; 三環系薬剤, モノアミンオキシダーゼ

d : 血管拡張性降圧剈 ; プラゾシン, ヒドララジン

$\mathrm{e} ：$ 中枢性降圧剤；メチルドーパ，クロニジン

$\mathrm{f} ：$ アドレナリン作動神経遮断剂；グアネシジン, ベタニジン

$\mathrm{g}: \alpha$ 遮断剤；フェノキシベンザミン，ラベタロール

$\mathrm{h}$ ：節遮断剤；へキサメソニウム, メカミラミン

$\mathrm{i} ：$ アンギオテンシン転換酵素阻害剤；カプトリル

II） 局所性機能障害
$\mathrm{A}:$ 眼
Holmes-Adie 症候群, Argyll Robertson 瞳孔, Horner 症候群
$\mathrm{B}:$ 涙腺, 唾夜腺
sicca syndorome?
C : 食道
アカラシア
$\mathrm{D}$ : 胃・十二指腸
消化性潰瘍?
$\mathrm{F}$ : 腸管
慢性特発性偽性腸閉塞 (chronic idiopathic intestinal pseudo-obstruction)
$\mathrm{F}$ ：大腸
Hirschsprung 病, 過敏大腸症
G：血管
Raynaud 病, Buerger 病, 閉塞性動脈硬化症
$\mathrm{H}:$ 汗腺
特発性多汗症，無汗症 
に対して，耳鼻咽喉科疾患の多くは機能性障害 と考兄られ，自律神経機能検査の結果が必ずし も一致しない点があげられる。我々も従来から 耳鼻咽喉科疾患と自律神経機能との関係を解明 しよらと試み，めまい疾患をはじめとしていく つかの疾患に対して自律神経学的検討を行って きた2)。後述するよらに，自律神経機能検査は 多数の種類があり，どのような検査を選択すべ きか，その結果をどのように解釈したら良いの かは重要な問題である。本論文ではこれらの点 に関して，メニエール病を中心にしためまい疾 患に対する当教室に拈ける成績をもとに述べる ことにする。

\section{自律神経機能検査について}

従来から自律神経系は，その遠心路を中心に 考えられて持り，節後線維の神経伝達物質が， ルアドレナリンである交感神経系と, アセチル コリンである副交感神経系とにわけられる。近 年神経薬理学の発達により,さまざまな神経ぺ プチドが神経伝達物質として見い出され，自律 神経系はアドレナリン作動性の交感神経系と， コリン作動性の副交感神経系といら区分だけで はないことがわかってきた3).しかしこれらの
神経ペプチドは生体内での役割の不明な点も多 く，それらの機能を検討する方法もないため， 従来からの交感神経・副交感神経といら考え方

\section{表 2 自律神経機能試験}

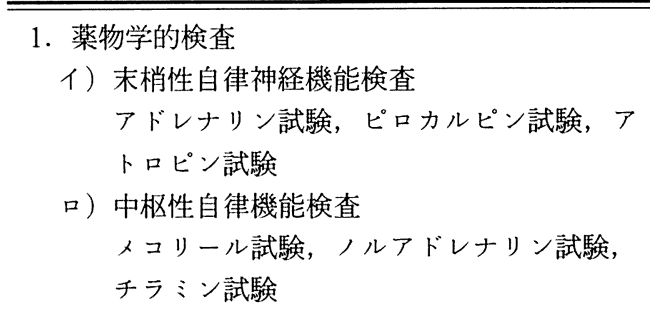

2. 理学的検查
イ）アシュネル眼球生迫試験
ロ）ツェルマクーヘーリング頸動脈洞圧迫試験
八）エルベン蹲踞試験
二）シェロング起立試験
ホ）ビュルグル加圧止息試験
一）ハイネスーブラウン寒冷昇圧試験
卜）皮膚絞画症の検査
チ）柕皮反応
リ）ケストネル皮鬳毛細管反応
邓）指尖容積脈波法
ル ) Microvibration 法
オ）その他

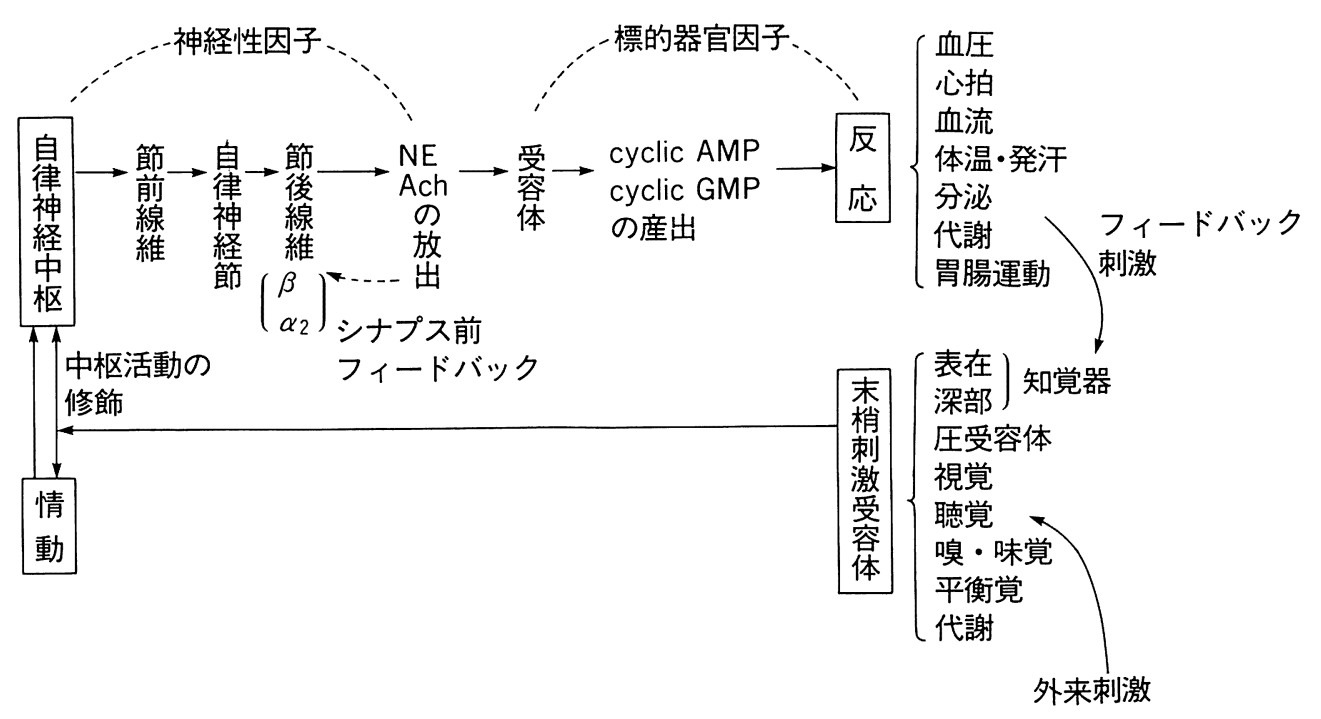

図 1 自律神経遠心路と求心路の相互関係 
表 3 自律神経系検査法の種類

\begin{tabular}{|c|c|c|c|c|c|}
\hline 哭管 & $\begin{array}{l}\text { 形態学的 } \\
\text { 検查法 }\end{array}$ & 生理学的検査法 & 生化学的検査法 & 薬理学的検査法 & 放射線学的検査法 \\
\hline $\begin{array}{ll} & \text { 瞳 } \\
\end{array}$ & & $\begin{array}{l}\text { 赤外線瞳孔撮影, 赤外 } \\
\text { 線電子瞳孔計（瞳孔面 } \\
\text { 積の測定と対光反応の } \\
\text { 定量化） }\end{array}$ & & 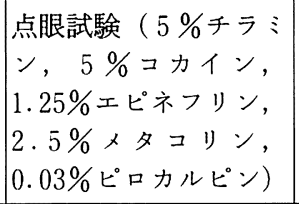 & \\
\hline 皮膚| & $\begin{array}{l}\text { 汗腺の組織学 } \\
\text { 的検査(光瀕, } \\
\text { 組織䖢光法, } \\
\text { 電顕) }\end{array}$ & 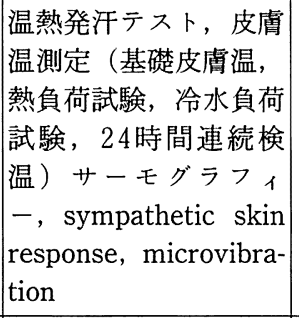 & & $\mid \begin{array}{c}\text { 発汗テスト（アセチル } \\
\text { コリン, =ュチン, ピ } \\
\text { ロカルピン, TRH の } \\
\text { 皮内注), 皮膚温測定 } \\
\text { (finalgon 軟高塗布), } \\
\text { ヒスタミ 塗布試験 }\end{array}$ & \\
\hline $\begin{array}{l}\text { 内分泌 } \\
\text { 外分泌 }\end{array}$ & & \begin{tabular}{|l} 
Schirmer テスト, \\
chewing gum テスト, \\
pilocarpine テストに \\
よる涙液分泌反応 \\
\\
\end{tabular} & $\begin{array}{l}\text { エピネフリン, ノル } \\
\text { ×ピネフリン, ドパ } \\
\text { ミン,DBH, MHPG, } \\
\text { HVA, 5-HIAA, } \\
\text { SRIF, レニン, } \beta \text {-エ } \\
\text { ンドルフィン, } \\
\text { Met-エンケファリ } \\
\text { ソ, プロラクチン, } \\
\text { TSH, GH }\end{array}$ & & \\
\hline $\begin{array}{ll}\text { 呼 } & \text { 吸 } \\
\text { 循 } & \text { 環 } \\
\text { 睡 } & \text { 眠 }\end{array}$ & & $\begin{array}{l}\text { 心電図 R-R 間隔変動 } \\
\text { 係数, 起立試験, 寒冷 } \\
\text { 升 圧 試 験, Valsalva } \\
\text { maneuver, Aschner } \\
\text { 試験, 頸動脈洞圧迫試 } \\
\text { 験, 頸 動脈洞反射検 } \\
\text { 查, 24時間 Holter 心 } \\
\text { 電図, ポリソムノグラ } \\
\text { フィー (心電図, car- } \\
\text { diotachogram, 呼吸, } \\
\text { 脳波, 眼球運動, 筋電 } \\
\text { 図) 指尖容積脈波 }\end{array}$ & & $\begin{array}{l}\text { 田中式自律神経検査 } \\
\text { 法, ノルエピネフリン } \\
\text { 静注試験, エピネフリ } \\
\text { ソ静注試験, イソプロ } \\
\text { テレノール静注試験, } \\
\text { チラミン試験, アトロ } \\
\text { ピソ試験, ピロカルピ } \\
\text { ソ試験 }\end{array}$ & $\begin{array}{l}\text { positron emission } \\
\text { tomography, SPE- } \\
\text { CT (脳循環) } \\
\\
\end{array}$ \\
\hline 消 化 管 & 直腸生検 & 肛門括約笳筋電図 & & & $\begin{array}{l}\text { 食道造影, }{ }^{99 \mathrm{~m}} \mathrm{Tc} \text { 標 } \\
\text { 識オムレツ試験食に } \\
\text { よる胃排出能 }\end{array}$ \\
\hline 膀脱 & & $\begin{array}{l}\text { シスメトリー, 尿道括 } \\
\text { 約筋筋電図 }\end{array}$ & & & \\
\hline 生 殖 器 & & \begin{tabular}{|l|} 
後部尿道, 陰茎（核） \\
の電気刺激による脳脊 \\
髄誘発電位 \\
\end{tabular} & & & \\
\hline 末梢神経 & $\mid \begin{array}{c}\text { 腓腹神経生検 } \\
\text { (光顕, 電顕) }\end{array}$ & $\begin{array}{l}\text { タングステン微小電極 } \\
\text { を用いたニューログラ } \\
\text { ム }\end{array}$ & & & \\
\hline
\end{tabular}


で自律神経系をとらえる方法が実際的であり， それに基づいて多数の自律神経機能検査法が報 告されている.

自律神経機能検査は, 従来表 2 に示す如く薬 物学的検查と理学的検査に分類されることが一 般的であっだ). しかし近年自律神経系は遠心 路のみならず求心路も含めて考无られるように なり（図 1)，自律神経系の中枢・末梢での神 経伝達物質や受容体, second messenger など の概念が次第に明らかになり，その定量が可能 になるにつれて, 表 2 で示した自律神経機能検 查以外の検査が多数行われるようになってきた. ちなみに黒岩5) は, 自律神経機能検査を効果器 および検査方法の面から, 表 3 の如くに分類し ている.

表 2 , 表 3 で示した多数の自律神経機能検査 の個々の方法の説明については本論文の主旨で はないため省略するが，自律神経系は図 1 に示 した経路から構成されており，この神経経路の どの部分が障害されても自律神経障害は発生す る.したがって施行した自律神経機能検査が, 自律神経経路のどの部分の機能を測定している のかを理解しておくことは, 検査結果の解釈に 重要である.

ひとりの患者に，これらの検査をすべて施行 することは不可能であり，目的にあった検査を 選択する必要があるが，一体どのような検査を 選択すれば良いのであろらか。

疾患と自律神経との関係には 2 種類のものが 考えられる。ひとつは疾患の結果生じる自律神 経異常であり，ひとつは疾患の原因と考学られ る自律神経異常である. したがって前者の自律 神経機能を検討する場合は，どのような自律神 経機能検查を用いても良いと考学るが，後者の 場合は, その自律神経異常がどのようなメカ二 ズムで疾患を惹起するかを推測し，その系の自 律神経機能検査を選択すべきである。たとえば 自律神経異常が内分泌系を介して疾患を惹起す ると考学るのなら，内分泌系の自律神経機能検 査を選択すべきであり，循環系を介して疾患を
苍起寸ると考光るのなら，循環系の自律神経機 能検査を選択すべきである.

めまい疾患の自律神経機能を検討する場合も 同様に考号られる，すなわち，めまい発作の際 前庭自律神経反射の結果生じた自律神経異常を 明らかにする場合は，どのような自律神経機能 検査を用いて自律神経機能を評価しても良いが， めまいの原因と考号られる自律神経異常を明ら かにするためには，その自律神経異常がどのよ らなメカニズムでめまいを惹起する可能性があ るのかを推測して, 自律神経機能検査を選択せ ねばならない，我々は従来から，めまいと椎骨 動脈血流との間の密接な関係を見い出してお り67)，もし自律神経異常がめまいの原因にな るとすれば，自律神経異常が循環障害（主とし て椎骨動脈系）をひきおこし，めまい発症につ ながると考光ている，つまり，めまいの原因と 考えられる自律神経異常を明らかにする目的で あれば，循環系自律神経機能検査を用いる必要 があると考える。

\section{めまいと自律神経機能}

めまいと自律神経機能との問題に，2つの側 面があることは前述した．すなわち，前庭自律 神経反射の結果として生じる自律神経機能異常 と, めまいの原因と考兄られる自律神経機能異 常である．実際の臨床でめまい患者に自律神経 機能検查を行ら場合, 得られた自律神経機能異 常がどちらなのかを厳密に区別することは困難 なことが多い。しかしどちらの自律神経機能異 常を明らかにしょらとしているのかは，常に考 慮しておかねばならない。

従来からめまいと自律神経機能との関係に関 して多数の報告8) 16) があるが，結論はまだで ていない，その理由として，採用した自律神経 機能検査が不適切である場合や，検査結果の解 釈が適切であるかどらかが問題となる。たとえ ば，従来 Eppinger らにより提唱されたアドレ ナリン試験に打いて，アドレナリンに過鄱に反 応した場合を交感神経機能充進としていたが， 現在ではこの状態は交感神経機能低下に基づく 
receptor の感受性亢進を反映していると考兄ら れて拈り，全く逆の解釈がなされている17).

自律神経系は図 1 に示した多数の因子により 構成されている。たと壳ば自律神経中枢の興奮 は, 神経線維, 神経伝達物質, receptor, second messenger を介して種々の反応をひきお こし, 逆にこれらの反応やその他の外因性刺激 が自律神経求心路を通り，自律神経中枢を興奮 させることが知られている，すなわち自律神経 機能は, 自律神経中枢の基礎活動に, 求心性刺 激に対する自律神経中枢の反射的調節活動の総 和によって規定されると考学られる．したがっ て，たとえば自律神経機能六進といら表現は， 自律神経中枢の基礎活動の亢進なのか，反射的 調節活動の亢進なのか，血圧，体温などの反応 の六進なのかを分けて考皇る必要がある。これ

表 4 循環器系自律神経機能の分類と定量的測定法

1. 自律神経自身の活動度の測定

○交感神経：血漿 NE 濃度, DBH 活性, 著者 らの $\alpha, \beta$-Secretion, cyclic AMP (?)

○副交感神経：アトロピン効果, cyclic GMP (?)

2. 標的器管（受容体）感受性の測定

$\mathrm{O} \alpha, \beta$-受容体刺激薬による循環器脳, c-AMP, NEFA, 血糖の変化

○Ach-受容体刺激薬（Ach，メコリール，ピ ロカルピン) の効果, c-GMP の変化

3. 自律神経活動の表現型の測定（神経活動 $\times$ 標 的器管感受性)

Ohexamethonium, guanethidine, propranolol, phentolamine, prazocine による循環 機能の変化量

○ atropine による循環機能の变化量

4. 自律神経反射機能の測定

○交感神経反射：起立台, 寒冷昇圧時の血漿

$\mathrm{NE}, \mathrm{DBH}, \mathrm{c}-\mathrm{AMP}$ 変化

O副交感神経反射 : buffer nerve function (昇

圧，降圧時の $\Delta \mathrm{R}-\mathrm{R} / \Delta \mathrm{mmHg}$ ），心電図 $\mathrm{R}-\mathrm{R}$ 間隔変動

5. non-autonomic component $の$ 測定 atropine + propranolol + phenotolamine $\left.\begin{array}{l}\text { (又は guanethidine) } \\ \text { hexamethonium }\end{array}\right\rangle$ 投与後の循環機能
らの観点から, 田中は循環系自律神経機能検査 を, 表 4 の如く分類している ${ }^{18)}$.

我々も以前から，ィニェール病をはじめとす るめまい患者の自律神経機能について，特にど のよらな自律神経機能異常が存在する時にめま いが発生するか，その自律神経機能異常がどの よらなメカニズムでめまい発症につながるかと いら点に興味を持って,ささざまな自律神経機 能検査を行ってきた．これらはめまい患者の全 身的あるいは局所的な自律神経機能を検討した ものであるが，我々の行った全身的自律神経機 能検査を田中の分類にしたがうと表 5 に示す内 容の検査が含まれる.以下に，主としてメニェー ル病を対象として得られたこれらの検査結果を 記述し，メニエール病に打ける自律神経機能に ついての私見を述べる。な怙個々の検査につい てはすでに発表されて㧍り，さらにそれらをま とめて松永 ${ }^{19)}$ は「自律神経機能とめまい」と いら総説を発表しているため, 今回は結果を簡 単に記すことにする。詳細はそれらの文献の一 読を勧める。

\section{メニエール病の自律神経機能}

I . 全身的自律神経機能検査

1. 自律神経自身の緊張度の測定

交感神経自身の緊張度の測定として，血漿， ルエピネフリンの測定を GC-MS を用いて20),

表 5 めまいに関する循環器系自律神経機能の分 類と定量的測定法

1. 自律神経自身の緊張度の測定 ○交感神経 : 血漿 NE 濃度

2. 標的器管感受性の測定

○血小板, リンパ球, $\alpha_{2}$ および $\beta$-adrenergic receptor

○ノルエピネフリン定速注入

3. 自律神経活動度の測定（緊張度 $\times$ 感受性）

○ $\beta$-blocker 静注による心拍数

○アトピロン静注による心拍数

4. 自律神経反射機能の測定

○起立負荷, 寒冷負荷, 圧受容器反射

O心電図 R-R 間隔（瞳孔反射） (Aschner) 
あるいは全自動カテュラミン分析装置 ${ }^{21)}$ によ って行った。

めまいのない時期では，メニエール病をはじ めとするめまい疾患の安静時血漿ノルエピネフ リン值は，健常成人と差を認めなかった 22)。一 方メニエール病のめまい発作時には, 血圧の上 昇とともに血漿ノルェピネフリン値の高值を認 め23)，この結果は一側耳を水水で温度刺激した

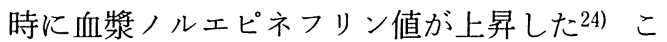
とと一致した。

以上よりメニェール病の間歇期の交感神経緊 張度は正常と考兄られ, めまい発作時には前庭 自律神経反射の結果交感神経機能が元進すると 考光られた。

2. 標的器官（受容体）感受性の測定

一定量のノルェピネフリンを点滴静注し，血 漿ノルェピネフリン值の上昇の程度と血圧の上 昇の程度とを比較することにより, 受容体（血 管平滑筋）の感受性を測定した ${ }^{22)}$.

メニェール病では反応域値は健常成人と差が ないが，反応性が有意に低值であった。この反 応性低下のパターンは, Polinsky ら 25) の報告 した交感神経緊張性起立性低血圧と呼ばれる起 立時に著明な脈拍増加を示す疾患の反応と類似 していた.すなわちメニエール病に打りる受容 体の反応性低下は, 交感神経緊張充進によるも のと考えられた。

しかし，ここで検討された受容体の反応性は， 受容体のみではなく受容体以降の反応発現に関 係する全機構が関与しているため, メニエール 病患者で認められた反応性の低下は, 必ずしも 受容体のみの感受性低下を意味しない。ちなみ にメニエール病患者のリンパ球 $\beta$ 受容体, 血小 板 $\alpha_{2}$ 受容体の数や親和性は健常成人と差がな (26) ため，メニエール病患者で認められた受 容体の反応性低下は, 受容体以降の反応性の低 下に起因している可能性があると考兄られる。

3. 自律神経活動の表現型の測定

自律神経の活動性は, 生体においては血圧, 心拍数などの形で表現されている. したがって
自律神経遮断剂の投与により生じた血圧，心拍 数などの表現型の変化を測定することにより， 自律神経活動の程度（自律神経影響度）を判定 することがでさる．この自律神経影響度は，自 律神経自身の緊張度と受容体の感受性との積に 相当すると考兄られる，実際には，安静時にプ ロプラノロールを投与した際の心拍数の変化 （徐脈の程度）により交感神経影響度を，アト ロピンを投与した際の心拍数の変化（頻脈の程 度）により副交感神経影響度を測定した ${ }^{27) . ~}$

メニエール病の病期を準発作期（頭位あるい は頭振後眼振を認め, めまいを訴えている時 期)，活動期（めまいを訴えているが眼振を認 めない，あるいは逆に眼振を認めるがめまいを 訴えいない時期), 間歇期（めまいも眼振も認 めない時期）とにわけて健常成人と比較すると， 交感神経影響度はいずれの病期でも健常成人と 差がなく，副交感神経影響度はいずれの病期に おいても有意に低值を示した.

自律神経影響度は自律神経緊張度と受容体の 感受性との積に相当するため, メニエール病患 者で認められた副交感神経影響度の低下は，必 ずしも副交感神経緊張度の低下を意味しないが， このような副交感神経影響度の低下の状態はい ずれの病期でも認められたため,メニエール病 の素因と考兄られる自律神経状態ではないかと 推測された。

4. 自律神経反射機能の測定

自律神経反射機能は図 1 に示したように，加 えられる刺激の強さ, 知覚受容器の感受性, 求 心路，中枢に扣ける求心性刺激の遠心性刺激へ の変換能力, 自律神経遠心路, 受容体の感受性 扣よび反応性という，反射弓全体の機能に依存 して評価されるために，検查結果の異常を中枢 に拈ける变換能力の異常に直接結びつけること はできない，しかし自律神経遠心路以降の経路 は, 前述の 1，2，3 の各自律神経機能検査で評 価することができる。また刺激に対する生体の 反応は，交感神経系，副交感神経系に同時に生 じるため，特に反射機能の評価には交感，副交 
感神経機能の両者の存在を常に念頭におかねば ならない.

いくつかの自律神経反射機能について検討し たが，以下簡単に結果を述べる。

(1) R-Rcv 検査

心電図 R-R 間隔の変動 $(\mathrm{R}-\mathrm{Rcv})$ は, Wheeler ら28)により提唱された自律神経機能検査で, 検查法が非侵襲的で簡便であることから，広く 行われている.この R-Rev は呼吸により反射 的に惹起される不整脈（呼吸性不整脈）の程度 を検討する方法で, 自律神経反射機能検査のひ とつであるが，アトロピンで変動が消失するこ とより副交感神経機能を反映すると考えられて いる29). しかし甲状腺機能立進症やアドレナリ ン投与時も R-Rcv は低下する30) ため, 交感神 経機能の影響も否定できない。

メニエール病に拈ける R-Rev の結果は以下 の如くであった27).すなわちメニエール病全体 では健常成人とは差を認めなかったが, 病期別 にみると, 準発作期では有意の低值を認め, 活 動期, 間歇期では正常であった，R-Rcv を用 いた自律神経反射機能の面からは，メニエール 病の準発作期では副交感神経機能の低下または 交感神経機能の克進が考えられた。

(2)シェロング試験

起立時の血圧, 心拍数の変化を検討するシェ ロング試験は，簡便な自律神経機能検査として 知られているが, 起立負荷による循環血液量の 減少を維持するための反射的な自律神経機能を 評価する方法である.この際交感神経, 副交感 神経がともに協調して循環血液量の維持に働く 訳である31) が, 従来から交感神経機能の面か ら評価されてきた．

シェロング試験陽性の判定を小児の起立性調 節障害の判定基準（1)収縮期血圧 $20 \mathrm{mmHg}$ 以 上の低下, (2)脈圧 $16 \mathrm{mmHg}$ 以上の狭小化, (3) 心拍数 21 /分以上の増加）にしたがうと, 入 ニエール病をはじめとするめまい患者で約半数 が陽性と判定されたが, 非めまい患者の対照群 と差を認めなかった. しかし年令別, 項目別に
両群間の陽性率を比較すると，39才以下の若年 のめまい患者で, 心拍数増加による陽性率が有 意に高く, 交感神経機能六進が示唆された6).

(3)圧受容器反射

生体では, 大動脈弓, 頸動脈洞に存在する圧 受容器の働きにより血圧の恒常性がはかられる。 すなわち血圧の昇圧時には圧受容器を介して副 交感神経の興奮性は亢進し, 交感神経の興奮性 は抑制され，心拍数の減少，血圧の下降がもた らされる，一方降圧時には副交感神経の興奮性 は抑制され，交感神経の興奮性は元進し，心拍 数の増加, 血圧の上昇がもたらされる.つまり 昇圧時, 降圧時ともに両自律神経機能は影響を 受ける訳であるが，昇圧時に生じた血圧上昇の 大きさと心拍数減少の割合で副交感神経機能を, 降圧時に生じた血圧低下の大ささと心拍数増加 の割合で交感神経機能を評価した。

メニェール病では, 発作から近い時期, 発病 から近い時期, 発作の頻発する時期に交感神経 機能の克進を認めた ${ }^{32}$.

II. 局所的自律神経機能

自律神経機能の左右差，すなわち局所的自律 神経機能検査としては，瞳孔反応を用いたもの が知られているが33) 35), 局所的自律神経機能 に抢いても循環系にあらわれる左右差を検討す る自律神経機能検査が重要と考兄, 以下の検査 を行った.

(1)水水負荷皮膚温測定法

本法は高橋ら ${ }^{36)}$ がパーキンソン病に対して 簡便な自律神経機能検査として報告した方法に 準拠したもので，両手を氷水に浸した後の皮膚 温の回復の左右差を検討した.メニエール病の 準発作期では高率に左右差を認め，活動期，間 歇期となるにつれて左右差出現率は低下し, 健 常成人での出現率と有意差を認めなかった，同 一症例においても，めまい発作時に認められた 左右差が間歇期には消失することが確かめられ た37).

椎骨動脈血流と皮膚温回復の左右差との関係 をみると, 椎骨動脈血流の左右差が存在する時 
には皮膚温回復の左右差も有意に高率に出現す ることが判明した。このことは椎骨動脈血流の 左右差と皮膚温回復の左右差が, 同一のメカニ ズムで発現する可能性を示唆する結果と考兄ら れた. しかしメニエール病の患側, 椎骨動脈の 血流不良側と皮膚温回復の不良側は，必ずしも 一致しなかった37).

手の皮膚血行は交感神経性の血管収縮線維に より支配され, 交感神経が過度に緊張する場合 や，血管壁の交感神経性刺激に対する反応が増 強する場合には, 内外の刺激によって血管は収 縮しやすくなるとされている38). したがって氷 水負荷後の皮膚温回復の不良は交感神経機能え 進を反映していると考えられ, 実際に交感神経 機能充進と考えられるレイノ一病に拈いて, 手 を冷却した後の皮膚温回復が不良であることが 報告されている38)。つまり本法で示された左右 差は, 頸部交感神経機能の左右差の反映と考兄 られた。

また前庭神経炎や内耳炎などではめまいのあ る時でも皮膚温回復の左右差は必ずしも認めら れない37) ため, メニェール病の準発作期で高 率に認められた左右差はめまい発作の結果では なく, めまい発症の原因ないし誘因ではないか と推測された。

(2)アシュナー試験

眼球圧迫により生じる徐脈の程度を検討する アシュナー試験は, 副交感神経機能検査として 知られているが, 我々は左右の眼球を打のおの 別々に一定の圧力で圧迫し, その際生じる徐脈 の程度を比較することにより, 左右差の検討を 行った.メニェール病に执いては健常成人と比 較し, 有意に反応の左右差を認めた ${ }^{39}$.

(3)前額部冷却試験（仮称）

前額部正中を氷のらで冷却した後の顔面頓部 皮膚温の変化を，サーモグラフィーを用いてそ の左右差について検討した.メニエール病活動 期では左右差を認めるものが多く, 間歇期ある いは健常成人と比較して有意であった．煩部皮 膚温変化の左右差も, 椎骨動脈血流の左右差の
存在と有意の相関を示した ${ }^{40)}$.

以上 3 種類の局所的自律神経機能検査におい て,いずれもメニエール病の準発作期ないし活 動期で高率に左右差を認め, それらは間歇期で は減少するといら共通の結果が得られた。

\section{メニエール病の自律神経機能についての考察}

従来から，さまざまな疾患が自律神経異常に 起因すると報告されている（表 1 ）。これらの 疾患の多くは, 症状が進行性, 非可逆性で, 自 律神経異常も器質的な低下と考えられる.この ような場合には自律神経機能検査の再現性は良 好で, 複数の検査結果は一致すると考えられる.

一方メニェール病をはじめとするめまい疾患 に打いては，その症状は可逆性であり，もし自 律神経異常が存在するとしても, その異常は器 質的障害ではなく，機能性障害が考えられた。 さらに，めまいと椎骨動脈血流とが深い関係を 有することから，自律神経異常が循環障害を介 してめまい発症につながるのではないかと考党 られた。したがってメニエール病の自律神経機 能の検討に循環系自律神経機能検査を採用した 訳だが，機能性障害の場合は疾患の経過によっ てもその機能が変化することが考えられ, 複数 個の自律神経機能検査を施行し，それらを総合 的に判断しなければ，メニエール病の真の自律 神経機能の評価は困難と考えた。そこで全身的 自律神経機能検査として, 表 5 に示した検査を 施行した。 また椎骨動脈血流の異常は, 特にそ の左右差がめまい発症と密接な関係を有するた め, 自律神経機能とめまい発症とのメカニズム の解明には, 自律神経機能の左右差の検討も不 可欠と考元，いくつかの局所的な自律神経機能 検査も施行した.

これらの自律神経機能検査の結果は前章で述 べた如くで, 局所的自律神経機能検査ではいず れの検査でもメニエール病の準発作期ないしは 活動期に拈いて著明な左右差を認め, その左右 差の存在は椎骨動脈血流の左右差と有意な相関 を示した.この自律神経機能の左右差は主とし て頸部交感神経機能の左右差と考えられるが, 
副交感神経系にも存在すると考えられた。また, この左右差は前庭神経炎などの症例では認めら れず,メニエール病のめまい発作の結果生じた ものではなく，原因と考学られる病態ではない かと考兄られた。すなわちメニエール病に执い て, 頸部交感神経機能の左右差が, めまい発症 に本質的な役割を演じていると考えられた。

一方, 全身的な自律神経機能検査の結果は必 ずしも検査ごとには一致しなかった，その原因 として，いくつかの理由が考えられる.

(1)今回検討したメニエール病は, 各検査ごと に患者構成が異っている.すべてのメニェール 病が同一の自律神経機能異常により発症すると は考えられないため, 患者構成の異っている対 象により得られる自律神経機能異常は異なる可 能性がある。

(2)メニエール病における自律神経異常は機能 障害と考えられ, 疾患の経過, 病期などにより, その機能が変化する可能性がある.

(3)自律神経機能は年令により生理的に变化す る ${ }^{41)}$. 各検査ごとに健常成人などをコントロー ルとして自律神経機能を評価したが，検査によ ってはメニェール病患者とコントロールとの年 令構成の差を考慮せずに自律神経機能を評価し ている.

(4)各自律神経機能検査のパラメータは必ずし も正規分布をしているかどらかは不明であるが， 正規分布と仮定して自律神経機能を評価したも のが多い、したがって，ある検査で評価された 自律神経機能が，他の検查でも同じ自律神経機 能として評価できるかどらか不明である。すな わち, ある検査で正常と判定された自律神経機 能状態が, 他の検査では充進または低下と判定 される可能性がある.

以上のいくつかの原因により，メニエール病 の全身的自律神経機能検査の結果が一致しなか ったと考えられる. しかし検査結果を総合的に 判断すると, 交感神経機能の相対的な充進がう かがわれた。

前述した如く, 自律神経系は多くの因子で構
成されているため, 多方面からの解析が可能で あるが，自律神経機能としては $2 つ の$ 側面から みることがでさる。すなわち安静時 (無負荷時) の自律神経機能と, 負荷時の反射的な自律神経 機能であり，それぞれ自律神経中枢の基礎活動 および，外因性刺激に対する自律神経中枢の反 射的調節活動に，注ぼ相当する。皇もそも自律 神経機能の本来の働きが homeostasis の維持で あるとすれば, 時々刻々と変化する外部環境に 対して, 反射的に内部環境を一定にする自律神 経反射機能が最も重要ではないかと考えられる. そこで著者は, 自律神経反射機能の検査として, 新たに起立時, 深呼吸時の心拍変動を指標とし た自律神経機能検查 ${ }^{42)}$ を現在行っている. 本 検査の詳細については後日報告する予定である ため省略するが，簡便で非侵襲的な検査である ため, メニェール病の経過に応じて頻回に検査 を施行することができる，さらに健常成人に自 律神経遮断剂を用いた結果より, 起立時の心拍 変動は主として交感神経機能を, 深呼吸時の心 拍変動は主として副交感神経機能を反映するこ とが知られている43).すなわち，ひとつのパラ メータ (心拍数) で交感神経, 副交感神経機能 をわけて検討することができるため，有用な自 律神経機能検査と考えられる.

今回は健常人で報告42)されている平均值 $(\mathrm{M})$, 標準偏差 $(\mathrm{SD})$ をもとに, $\mathrm{M} \pm 1 \times \mathrm{SD}$ 以内を正 常, $\mathrm{M} \pm 1 \times \mathrm{SD} \sim \mathrm{M} \pm 2 \times \mathrm{SD}$ を軽度六進（低 下), $\mathrm{M} \pm 2 \times \mathrm{SD}$ 以上（以下）を充進（低下） と判定し, さらに両自律神経機能の相対的な比 較により, 相対的交感神経優位, 相対的副交感 神経優位についても検討した。

結果は表 6 (間歇期), 表 7 (準発作期, 活 動期）に示す如くで, メニェール病ではいずれ の病期においても交感神経機能, 副交感神経機 能ともに低下を示すものが高率であったが，相 対的な自律神経機能は間歇期では相対的副交感 神経優位, 準発作期, 活動期では相対的交感神 経優位を示すものが高率であった．また同一症 例に打ける経過による自律神経機能の推移をみ 
ると, 副交感神経機能は有意の変化は示さず, 交感神経機能は準発作期, 活動期では間歇期と 比較し克進するものが有意に多数であった。し かし交感神経機能そのものは, 健常人と比較す ると準発作期, 活動期においても，低下を示す ものが多かった ${ }^{44)}$.つまりメニエール病では, 間歇期には交感神経機能, 副交感神経機能とも 低下しているがその程度は交感神経機能低下の 方が大きく, 相対的な自律神経機能は副交感神 経機能優位となっている. しかし準発作期や活 動期になると, 交感神経機能は健常人と比較す れば低いものの, 間歇期に比べると充進し, 一 方副交感神経機能低下は不変で, 相対的な自律
神経機能としては交感神経優位を示すものが多 くなると言える。

今回の我々の結果も含めて, メニエール病の 全身的な自律神経機能をどのように解釈したら 良いであろらか。

副交感神経機能については，比較的一定の結 果が得られた。すなわち，自律神経中枢の基礎 活動を比較的反映すると考えられる自律神経影 響度の検查に抢いても，自律神経中枢の反射的 調節活動を反映すると考学られる今回の我々の 結果でも，ともに機能低下を示す結果が得られ た. 特に病期によっても副交感神経機能低下の 程度は不変であり, これらの結果は，メニェー

表 6 間歇期の自律神経機能

\begin{tabular}{|c|c|c|c|c|c|c|}
\hline 交感 & $\downarrow$ & $\downarrow$ & 正 & $\uparrow$ & $\hat{1}$ & 計 \\
\hline$\nabla$ & 5 & 1 & 7 & 3 & & $16(28.6)$ \\
\hline$\downarrow$ & 2 & 1 & 7 & & & $10(17.9)$ \\
\hline 正 & 5 & 3 & 11 & 5 & & $24(42.9)$ \\
\hline \multirow[t]{2}{*}{$\uparrow$} & & & 3 & & 1 & $4(7.1)$ \\
\hline & & & 1 & & 1 & $2(3.6)$ \\
\hline \multirow[t]{3}{*}{ 計 } & $\begin{array}{c}12 \\
(21.4)\end{array}$ & $(8.9)$ & $\begin{array}{c}29 \\
(51.8)\end{array}$ & $\begin{array}{c}8 \\
(14.3) \\
\end{array}$ & $\begin{array}{c}2 \\
(3.6)\end{array}$ & 56 \\
\hline & \multicolumn{2}{|c|}{$17(30.4)$} & \multicolumn{4}{|c|}{$10(17.9)$} \\
\hline & & & \multicolumn{2}{|c|}{$\begin{array}{l}\text { 相対的副交感神経優位 } \\
\text { 相対的交感神経優位 }\end{array}$} & $\begin{array}{l}24 / 56(4 \\
14 / 56(2\end{array}$ & ( ) $: \%$ \\
\hline
\end{tabular}

表 7 活動期，準発作期の自律神経機能

\begin{tabular}{|c|c|c|c|c|c|c|}
\hline 交感 & 7 & $\downarrow$ & 正 & $\uparrow$ & 1 & 計 \\
\hline 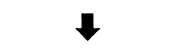 & 3 & 2 & 3 & 2 & 1 & $11(22.4)$ \\
\hline$\downarrow$ & 3 & 2 & 6 & 1 & & $12(24.5)$ \\
\hline 正 & 2 & 6 & 6 & 2 & 1 & $17(34.7)$ \\
\hline$\uparrow$ & 2 & & 3 & & & $5(10.2)$ \\
\hline 1 & & 1 & 2 & 1 & & $4(8.2)$ \\
\hline 計 & $\begin{array}{c}10 \\
(20.4)\end{array}$ & $\begin{array}{c}11 \\
(22.4)\end{array}$ & $\begin{array}{c}20 \\
(40.8)\end{array}$ & $\begin{array}{c}6 \\
(12.2)\end{array}$ & $(4.1)$ & 49 \\
\hline & 2 & & & & & \\
\hline
\end{tabular}

相対的副交感神経優位 $18 / 49(36.7)$

相対的交感神経優位 $\quad 20 / 49(40.8) \quad(\quad): \%$ 
ル病において副交感神経機能が素因的に低下し ている可能性を示唆すると言える.

副交感神経機能が充進していると考えられる 疾患のひとつに，十二指腸潰瘍がある ${ }^{1)}$. ニ = エール病も十二指腸潰瘍も, ともにストレスが 発症要因として重要視されているが, 両疾患の 合併例は必ずしも多くはなく，むしろ少ないと いう印象を持っている臨床家が多い27)。このこ とは, 両疾患の自律神経機能の相違を考えると 興味深い.

一方交感神経機能については，検査ごとにさ まざまな結果が得られた。この原因として先に 述べた理由以外に，めまい発作の際に惹起され た交感神経機能元進の影響をどの程度受けるか により，評価される交感神経機能に差がでる可 能性がある。また交感神経機能の評価を血圧な どの $\alpha$ 作用で行う場合と，心拍数などの $\beta$ 作用 で行う場合で差がでることも考えられる.ささら に自律神経機能検査において, 交感神経機能, 副交感神経機能とわけて評価しているが，実際 にはすべての検査において拉いの自律神経は 影響しあっており，純粋に交感神経機能のみ， 副交感神経機能のみを評価することは困難であ る.したがって副交感神経機能が低下している 場合には，たとえ交感神経機能が正常であって も，両者の影響の程度によっては，低下した副 交感神経機能に影響されて, 自律神経機能検査 の結果からは交感神経機能立進といら判定がな されることが考えられる.

以上のような問題もあり，メニエール病に特 徵的な交感神経機能は見い出すことができなか った.しかし, 起立時, 深呼吸時の心拍変動を 指標とした今回の我々の自律神経機能検査では, 交感神経機能も副交感神経機能もともに高率に 低下しているといら結果が得られた。すなわち, 交感神経機能低下といら状態がメニエール病に 高率に存在すると考えられ，特に間歇期により 著明であった．このことはどのように解釈すべ きであろらか。

自律神経系は, 交感神経と副交感神経とが各
臓器に対して拮抗的に作用し, 各藏器の反応を 調節している.すなわち, 生体にとって自律神 経機能が意味を持つのは, ただ単に交感神経機 能と副交感神経機能の独立して働く機能ではな く，両者の協調作用によってもたらされる各蔵 器の反応と考えられ，適切な反応をコントロー ルすることが homeostasis につながると考学ら れる。つまり自律神経系において，一方の機能 が変化すれば, 生体は他方の機能も変化させ, 両者の総和である反応性を調節すると考えられ る. 我々は, メニエール病患者の副交感神経機 能がいずれの病期でも同じ程度低下しているた め, 副交感神経機能低下がメニエール病の素因 と推測したが，この際生体は交感神経機能を低 下させ，適切な臓器反応性をコントロールする といらことは，十分考えられることである。ま たメニエール病に打いて，めまい発作時には交 感神経機能は明らかに六進するが，自律神経系 の働きを合目的論的に解釈すれば，生体はめま いの際惹起される交感神経機能充進状態を避け るために，交感神経機能を低下させると考えら れる. 以上のような理由により，メニェール病 において交感神経機能の低下が認められたので はないかと考学る。この場合，メニエール病の 自律神経機能にとって副交感神経機能低下が本 質的なものであり，交感神経機能低下は素因的 な副交感神経機能低下に対処するため，あるい はめまい発作により生じる交感神経機能穴進に 対処するためにもたらされた 2 次的なものであ り，したがってその程度によりさまざまな交感 神経機能状態が考えられ，そのことも，種々の 自律神経機能検査において交感神経機能検査の 結果が一致しなかった一因とも考えられた.

以上当教室で施行した自律神経機能検査の結 果をもとに,メニエール病の自律神経機能につ いて検討し，全身的な自律神経機能の面からは 副交感神経機能低下が素因，局所的な自律神経 機能の面からは頸部交感神経機能の左右差が誘 因と考えられる自律神経機能状態と推測された． このような自律神経機能状態ではストレスによ 
り生じる交感神経機能九進が増強され, そのこ とが生理的にも生ずる可能性のある頸部交感神 経機能の左右差とあいまって椎骨動脈血流の左 右差を惹起しめまい発症につながると考兄られ た。

メニエール病の自律神経機能について, 著者 の独断による私見を述べたが，すべてのメ二 エール病が自律神経異常に起因するとは考えら れず，また現在までの自律神経機能の評価方法 （健常成人の值をもとに正常, 異常を判定する) がはたして妥当なのか，すなわち自律神経機能 に正常範囲を定めることに若干の疑問も感じて おり，今後の検討課題としたい。

\section{参考文献}

1）後藤由夫, 本鄉道夫：自律神経の概説. 自律神 経の基礎と臨床（後藤由夫, 松雄 裕, 佐藤昭 男編). 12〜23頁, 医薬ジャーナル, 大阪, 1987.

2）荻野 仁, 田中美由起, 松永 亨: 2,3 の耳 鼻科疾患の自律神経機能. 耳鼻臨床 $79: 1914$, 1986.

3）千葉胤道：頭部拈よび頸部の自律神経. JOHNS $5:$ 789 793, 1989.

4）金井 泉, 金井正光編 : 自律神経機能検査法. 臨床検査法提要（第28版）。金原出版, 東京, 1978.

5）黑岩義之：自律神経のトピックス. Clinical Neuroscience $6: 888 \sim 893,1988$.

6）松永 亨：めまいの発生機序一自律神経系の関 与について一. 日本耳鼻咽喉科学会第84回総会 宿題報告. 1983.

7）津田 守：めまい患者に扰ける椎骨動脈血流動 態およびその修飾因子について. 日耳鼻 89 : 886 898, 1986.

8）日前健介：メニエール氏病患者の自律神経機能 状態関する研究. 耳鼻と臨床 6 増 $3: 254$ 282, 1960 .

9）田口喜一郎, 宮島靖彦：めまいに対する自律神 経機能検査, 特にその診断的意義. 耳喉 35 : 891 899, 1963.

10）白岩俊雄, 植木佳示, 田村 伝, 他 : メ二エ儿症候と自律神経機能.耳展 $6: 352 \sim 360,1963$.

11）野末道彦, 徳増厚二, 坂田英治, 他：末消迷路
疾患に関する臨床的研究（その 2) Mecholyl Test, Schellong Test, 点状皮虐電気抵抗低下現 象からみた末消迷路疾患の自律神経機能.耳喉 $37: 105 \sim 114,1965$.

12）桂万寿美, 上村卓也, 徳永恵美子, 他：めまい 患者の経過とメコリール検査成績. 日耳鼻 74 : 484 485, 1971.

13）宮田英雄, 時田 喬: メニェール病症例の発作 前後の自律神経状態.耳鼻臨床 69 増 $4: 1800$ $\sim 1806,1976$.

14）鲁山正邦, 宮田 学, 塩 栄夫：めまいを伴う 諸疾患における血清ドーパミン- $\beta$-水酸化酵素 活性. 耳鼻臨床 73 增 $4: 1941-1948,1980$.

15) Pappes DG, Crawford $W$ and Coghlan HC : Dizziness and the autonomic dysfunction syndrome. Otolaryngol Head Neck Surg $94: 186$ $\sim 194,1986$.

16）神田憲一, 大橋直樹, 将積日出夫, 他：めまい ・平衡障害と自律神経機能障害一 $\mathrm{RR}$ 間隔とシ ェロンテストー.耳鼻臨床 $80: 12 ; 1801 \sim 1806$, 1987.

17）田中信行, 川本和美 : 定量的自律神経機能検査 法. 神経内科 $14: 1 ; 25 \sim 31,1981$.

18）田中信行, 川本和美 : 循環器系自律神経機能の 定量的分析法. 脳神経 $36: 415 \sim 421,1984$.

19）松永 亨：自律神経機能とめまい。耳鼻臨床 $80: 865 \sim 878,1987$.

20）吉田淳一, 吉野邦俊, 松永 亨: 耳鼻咽喉科領 域疾患とカテューラミン（第一報）ガスクロマ トグラフィー質量分析計による血中ノルェピネ フリンの定量. 日耳鼻 $82 ： 541 \sim 546,1979$.

21) Yamatodani A and Wada H : Automated analysis for plasma epinephrine and norepinephrine by liquid chromatography incluing a sample clean up procedure. Clin Chem 27 : 1983 1987, 1981.

22）吉田淳一：めまい患者の自律神経機能. 日耳鼻 $86: 4 ; 421 \sim 429,1983$.

23）吉田淳一, 吉野邦俊, 岡田益明, 他：メニエー ル病発作中の血圧と血中ノルエピネフリンの関 係. 耳鼻臨床 75 増 $1: 161 \sim 166,1982$.

24）岡田益明, 吉田淳一, 松永 亨: カロリックテ ストに抢外血中カテュラミンと血圧との関係. 日耳鼾 $86 ： 1005 〜 1009,1983$. 
25) Polinsky RJ, Kapin IJ, Ebert MH, et al : Pharmacologic distinction of different orthostatic hypotension syndrome. Neurology $31: 1 \sim 7$, 1981.

26）前田一：メニエール病におけるアドレナリン 性受容体. 日耳鼻 $87: 805 \sim 812,1984$.

27）荻野 壬：メニエール病の自律神経機能につい て. Equilibrium Res $44: 1 ; 35 \sim 37,1985$.

28) Wheeler $\mathrm{T}$ and Watkins $\mathrm{PJ}:$ Cardiac denervation in diabetes. Br Med J 4 : 584 586, 1973.

29）黑田信稔, 谷口 洋, 馬場茂明 : 心拍変動の薬 理学的検討. 自律神経 $26: 129 \sim 133,1989$.

30）持尾聰一郎, 桑田隆志, 浅野次義, 他 : 心電図 $\mathrm{R}-\mathrm{R}$ 間隔の変動を用いた自律神経機能検査法 の問題点一交感神経機能の影響の有無一. 神経 内科 $18: 403 \sim 405,1983$.

31）森 英俊, 西條一止：自動・他動体位变換と心 拍数の変化一臥位, 立位の変換一. 自律神経 $23: 361 \sim 366,1986$.

32）松永 亨, 川菩良明, 武田憲昭, 他：めまい患 者の自律神経機能一反受容器反射による検討一 前庭機能異常調査研究班平成元年度研究報告書. 93 96, 1990 .

33) Uemura $\mathrm{T}$, Itoh $\mathrm{M}$ and Kikuchi $\mathrm{N}$ : Autonomic dysfunction on the affected side in Meniere's disease. Acta Otolaryngol 89 : 109 117, 1980.

34）竹田真知子：メニエール病患者の瞳孔反応. 日 耳鼻 $89: 275 \sim 287,1986$.

35) Ionue $\mathrm{H}$ and Uemura $\mathrm{T}$ : Sluggishness of pupillary light contraction in patients with Meniere's disease. Acta Otolaryngol $105: 582$ $\sim 586,1988$.

36）高橋光雄, 今岡弘之：パーキンソン病における 自律神経障害一水水負荷皮膚温測定法による検
討一. Pharma Medica $2: 7 ; 87 \sim 90,1984$.

37）荻野 仁，田中美由起，松永 亭：めまい患者 の自律神経機能一特にノニエール病における左 右差について一.耳鼻臨床 補 8 ：191〜200, 1986.

38）三島好雄 : 末梢血管,自律神経の基礎と臨床(後 藤由夫, 松雄 裕, 佐藤昭男偏). 170 179頁, 医薬ジャーナル，大阪， 1987.

39）落合 薰, 武田憲昭, 荻野 壬, 他：メニエー ル病患者の自律神経機能について（アシュナー テストを用いて). Equilibrium Res Suppl 4: $84 \sim 87,1988$.

40）落合 哑, 武田憲昭, 肥塚 泉, 他：メニエー ル病患者の自律神経機能についてーサーモグラ フィーを用いて一. Equilibrium Res Suppl 6 : $92 \sim 93,1990$.

41）間野忠明，岩瀬 敏：自律神経と加秢. 臨床成 人病 $19: 1363 \sim 1368,1989$.

42）及川 登：心拍数変動を用いた糖尿病性自律神 経障害の定量的評価 (第 1 報)一自律神経障害 判定のための基準值の設置一. 糖尿病 26 : 1123 1131, 1983.

43）及川 登：心拍数変動を用いた糖尿病性自律神 経障害の定量的評価（第 2 報）一交感・副交感 神経機能障害の鑑別一. 糖尿病 $27: 489 \sim 495$, 1984.

44）松永 亨, 荻野 仁：起立時および深呼吸時の 心拍変動より見たメニエール病患者の自律神経 機能. 前庭機能異常調査研究班平成元年度報告 書, 102 103, 1990.

$$
\left(\begin{array}{l}
\text { 別刷請求先 : 荻野 仁 } \\
\text { 干541 大阪市中央区大手前1-5-34 } \\
\text { 大手前病院耳鼻咽喉科 }
\end{array}\right)
$$

